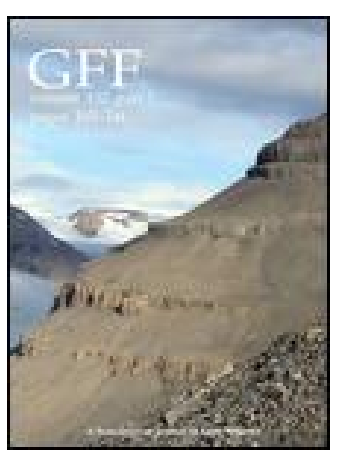

Geologiska Föreningen i Stockholm Förhandlingar

ISSN: 0016-786X (Print) (Online) Journal homepage: http://www.tandfonline.com/loi/sgff19

\title{
Kvartära nivåförändringar i östra Finland
}

\section{W. W. Wilkman}

To cite this article: W. W. Wilkman (1913) Kvartära nivåförändringar i östra Finland, Geologiska Föreningen i Stockholm Förhandlingar, 35:2, 157-158, DOI: 10.1080/11035891309443134

To link to this article: http://dx.doi.org/10.1080/11035891309443134

$$
\text { 曲 Published online: } 06 \text { Jan } 2010 .
$$

Submit your article to this journal ๔

Џ Article views: 4

Q View related articles $₫$ 
GEOr. FöREN. FörhANDL. Bd 35, H. 2. Febr. 1913. 157

\title{
Anmälauden och kritiker.
}

\author{
W. W. WILkMax: Keartära nivaförändringar $i$ östra Finland. \\ 40 sid. 9 fig. i texten. Bull. Comm. geol. de Finlande. \\ N:o 33. Helsingfors 1912.
}

Tid sina undersökningar inom det geologiska liartbladet :Joensuu bar förf. iakttagit och uppmätt ctt stort antal gamla strandlinjer, hvilket material gifvit upphof ât föreliggande slirift. Obserrationslokalcrna fơr den högsta marina gränsen äro inalles 13 och fördelade ofver ett område, som intager NE:a delen af huopio län och inrymmer bl. a. de ausenliga sjüarna Pielisjärri och Hüytiäinen. Forf. anser sina värden si allmänhet tämligen säkras och har äfren uppritat isobaser öfver den senglaciala sänkningen. Sålunda inkommer $190 \mathrm{~m}$ isobasen $\mathrm{i}$ området frắn $\mathrm{W}$ till närheten af Joensuu, där den liurrar af mot $\mathrm{N}$. 180 och $170 \mathrm{~m}$-isobaserna hafva däremot ett i lufrudsak W-E:ligt förlopy med en flexur norr ut något $\mathrm{E}$ om Joensuu. Det supramarina af området samlade sig denna tid till nuvarande Maanselkä, medan hela trakten W och $S$ om Joensuu var hafbetảckt. Orikedomen var nämare Maanselkï ganska stor tack vare den brutna relieffen.

Förutom MI.G. har förf. ialttagit och uppmätt långa serier af ofta väl utpräglade strandlinjer, dels senglaciala, dels frăn ancylustidens föra del. Dessa strandlinjer hafra uppdelats i tre grupper, motsrarande $i$ procent af $M$. G.: $92-79,76-70$ samt $66-63$. Alldenstund från en nivå motsrarande c:a $65 \%$ af M. G. och nedăt leraflagringar möta, som enligt undersökning af LINDBERG föra rikligt med sötvattensdiatomaceer, ofta af typiska ancylusformer, antager förf., att strandlinjerna tillhörande den sista gruppen utbildats af Ancylussjön. Han anför ej, săsom man också beträffande så pass centralt belägna traliter af det fennosliandiska området har sliăl att förränta, nâgon transgressionsgräns, som skulle motsrara Ancylusgränsen, utan săger i stället, att det senglaciala hafvet uppenbarligen smáningom öfrergått i Ancylussjön.

Vid den tidpunkt, då Salpausselkä höjde sir öfrer vattnet, afsnördes betydande vattenarealer $i$ det inre af Finland från förbindelsen med Ancylussjön. (Berghell, Wilkias). Den sålunda uppkomna xcen- 
tralfinska insjon inregistrerade sin tillvaro i tydliga strandlinjer, en del på 110-100 $m$-nivåer, en annan del c:a $95 m$ ö. h. De förra motsrara en tid, då Imatra ännu ej existerade. Utloppet var då san. nolikt genom hymmene älfdal. (BERGMELL).

Slutligen ägnar förf. ett kapitel àt föreliomsten af ssublakustrinas torflager, som anträffats rid stränderna af Pyhäsellä, Orivesi och Höytiäinen några meter öfver sjöarnas yta och täckas af ssrämsand, ssvämleras eller sflygsands. Denna öfverlagring är enligt förf. ett beris för att en transgression ofver torfven ägt rum, som sedermera utbytts mot en regression. Vaxtresterna äro af arter, hvilka trifras på långgrunda, sumpiga stränder. Torfven hvilar icke sällan på leror, förande ancylusdiatomaceer (LINDBERG). Förf. ser orsaken till strandförskjutningarna icke $\mathrm{i}$ cn afdunstningsföreteelse $\mathrm{j}$ enlighet med SERNANDERS teori, utan i rätt komplicerade nivåförändringar, frân $\mathrm{SE}$ till NW gående srågformiga oscillationers. Beträfiande den af en strandvall öfvertäckta torfven vid Höytiäinens S-ända måste man väl antaga, att en förskjutning mot $S$ af sjöns rattenmassa vid tiden for litorinahöjningen bragte torfven till det djụa läge, den ägde före uttappningskatastrofen 1869 , eller $8,5 \mathrm{~m}$ under den dåtida sjöytan. Förts. åsikt, satt en (lokal landhôjnings-)rågkam framgick öfver Jaamankangas. (S om Höytiäinen) mot NW soch efterföljdes af en rågdal, hwarvid Höytiäinens torflager (som under den föregående höjningen bildats) öfversvämmades af vattnets, synes däremot icke hafra fullt bindande skäl för sigr. Höytiäinens utlopp, som tidigare ledt mot $\mathrm{W}$, förlades $i$ och med vattenstjälpningen söder ut till tröskeln vid Jåmankangas.

H. $\mathrm{H}-\mathrm{N}$. 